DOI http://dx.doi.org/10.18551/rjoas.2016-03.01

\title{
MEASUREMENT OF TECHNICAL EFFICIENCY THAT INVOLVING FARMERS PREFERENCES TOWARDS RISK OF RICE FARMING IN MALANG (INDONESIA)
}

\author{
Agustina Shinta* \\ Faculty of Agriculture, Universitas Brawijaya,Indonesia \\ Budi Setiawan, Ratya Anindita \& Syafrial \\ Department of Agribusiness, Faculty of Agriculture, Universitas Brawijaya, Indonesia \\ *E-mail: shint4 71ub@yahoo.com
}

\begin{abstract}
The aim of this research is to analyse the level of technical efficiency of rice farming by considering farmer preferences towards natural and technological risks. This research is conducted in selected regions in Malang Regency (Indonesia) with the consideration that farmers in selected areas can produce high productivity, but productivity growth fluctuates very sharply each year (within 13 years). Natural phenomenon that often appears as the risks of farming, such as, floods, droughts, and hurricanes. While, the application of technology is the part of the risks of farming, too, because farmers are not willing to adopt the technology which facilitated by the government. Rice farmers who used respondents are 305 people namely spread in seven selected regions in two seasons. The method used are a) Expected Utility of Money to measure the farmer preferences towards the risks and b) Stochastic Frontier Translog production function with Maximum Likelihood Estimation (MLE) approach to analyse the level of technical efficiency of farming. The results found that $77.7 \%$ of farmers have averter risk preferences, the level of technical efficiency obtained at 0.75 by pooling the data, and the influence of the preference of farmers to sources of technical inefficiency is -0622 . Recommendation submitted is induced the technology with mentoring system and immediately implement the agricultural insurance.
\end{abstract}

\section{KEY WORDS}

Translog production function, agriculture insurance, inputs allocation.

During this time, the program has been conducted more by the government in Malang Regency (Indonesia), such as induction technology, investment in research, extension, development of human capital, and infrastructure improvements such as irrigation, the use of superior seeds, field school of integrated pest, credit programs, support programs in the form of support seed, fertilizer subsidies, organic fertilizer subsidized, post-harvest management and institutional. The latest program from the Ministry of Agriculture of Indonesia (2015), the government established a special working group efforts to increase the production of rice, corn and soybeans in the framework of self-sufficiency in 2017 with cost quite a lot. Those programs are expected to increase the productivity which impact on increasing farmers' income by improving the efficiency of input use.

In addition to the program, the government of Indonesian have policy on the price that can guarantee the stability of input-output prices and prevent farmers' income not fluctuated from season to season and constantly increasing. However, the conditions of market competition in the food crops actually often happens is imperfect, so the strength of the economy may affect the operation of the market system. Induction technology, policy and government programs cannot be effective depending on the farming decision makers. The decision-maker will get a good result, when based on precision in defining a decision. However, when faced uncertainty, then the decision will be at risk towards the favourable or unfavourable consequences. So that the individual's perception of the risk from the decisionmakers involved in the election action process. Limited knowledge of farmers on the application of technology, anticipation of the season shift, natural phenomena such as 
droughts and hurricanes, rodents and pests attacks such as leafhoppers and rice blast disease (Pyricularia grisea), the market, and also other phenomena that cannot be controlled by farmers, causing farmers constantly faced with the problem of uncertainty in profit.

The uncertainty will affect the behaviour of farmers in addressing how to make decisions in allocating inputs in order to reduce or avoid the risk of production, so it will affect the production to be achieved and lack of attainment in maximizing profits. According to Ellis, 1988 and Wik, et al., 1998 that avoidance behaviour towards the risk of production will cause the resulting production will be lower than the farmers who behave prefer to face the risk, so that an impact on the low income due to the low or unwillingness of farmers in adopting technology. There are three possible farmers preference in the face of the risks of farming, such as (a) risk averter is behaviour of farmers who prefer to avoid the risk, (b) risk neutral is the ordinary attitude on the risks that may be encountered and (c) risk taker is the brave behaviour of farmer in the face of risk. According to Ellis (1988) that the behaviour of farmers in the face of risk will affect productivity and farm income. The more courageous farmers against possible risk of loss, the greater the farmers tried to increase the production. Risk taker farmers are more efficient in allocating inputs in order to obtain maximum production, while risk averter farmers will suffer inefficiencies due to face problems in determining how big decision requesting input and how large output will produce.

Influence the allocation of inputs to the average production that built with production function stochastic frontier by Aigner, et al., (1977) and Meeusen and Van den Broeck (1977) as well as frontier production function deterministic built by Farrell (1957) and Aigner and Chu (1968) did not involve the risk of the production. The fact of production risk is an aspect of uncertainty of production which is very important in the formulation of government policy and decision-making by farmers according to Just and Pope (1978), Pope and Kramer (1979), Griffiths and Anderson (1982). According Battese, et al., (1995) that incorporate the risk of production on stochastic frontier production function is the essence of things related to the production of technical efficiency, since the measurement of technical efficiency measures the degree of usefulness of the technology adopted in the production process.

Research of efficiency by incorporating elements of the production risk has been successfully done by several researchers, such as Saptana (2012) on chily crops and Fauziyah (2010) in tobacco plants. From some research, rice commodities in developing countries on average show the level of technically efficient (Mailena, et al., Watkins, et al., Lawal, et al., Athipanyakul, Galawat and Yabe, Piya, et al., Hossain, et al., Donkoh, Islam et al, and Kurniawan ), however several other research have shown despite the high technical efficiency is not always high in allocative and economic efficiencies.

While, some research have found that the rice commodity are not yet technically efficient: Gosh and Raychaudhuri, 2010, for organic rice are efficient began in the fifth and seventh years (Prayoga), when compared with the efficiency of conventional products; the efficiency of organic products are lower (Karagiannias (2003), Charyulu (2010), Poudel, et al (2011). Research above found that the level of efficiency in allocating inputs of rice farmers is around $0.4-0.9$.

The potential of the Malang Regency is quite large in order to increase the production and productivity of rice, since this area has a fairly supportive environment. Biophysical environment such as air temperature and humidity between $23-30^{\circ} \mathrm{C}$, alluvial soil fertility conditions and andosol which is a type of land suitable for rice crop, rainfall between 1500$2000 \mathrm{~mm} /$ year, altitude of 0-1500 AMSL, enough sunlight, as well as water sources. Socioeconomic environment that is enough to support such as labour, easy access on market input and output markets, easy access to capital, high purchasing power, easy access to technology and information, educational opportunities and counselling are quite open, adequate infrastructure support. The political environment includes government policies quickly conveyed to the public as close to the relevant institutions such as the Department of Agriculture, Food Security and Extension Executive Board, and Agricultural Extension Centres. As well as demographic environment such as experience to farm, farmer groups and participation in education. 
Despite the potential, but the environment over there that can be controlled by the farmer depends on the managerial capacity of farmers to manage the farm, and some beyond the control of farmers caused by natural phenomena, it causes uncertainty of production produced by farmers. With rice land ownership by farmers who are not so large in Malang Regency, risk of farming uncertainties facing the greater influence to the allocation of input and impact on productivity. It difficult for the farmers to achieve efficiency. A combination of production factors and production risks would put farmers in a position to improve the efficiency and welfare levels. Uncertainty of production caused by the behaviour of the production risks will have an impact on the level of technical inefficiency.

Ureta, B, E. and Antonio E. Pinheiro (1997) suggested that one of the factors causing the decline in productivity is the technical inefficiency. Kumbakhar (2002) suggests that the production of a commodity affected by whether or not the allocation efficiency of input use, presence or absence of technical inefficiency problems related to the managerial capability of farmers, and the risk factors of production in farming.

Numerous researches above finding that the factors influencing the level of technical inefficiency of farmers were age, old farm, participation in farmer groups, the number of families, education, land ownership, access to credit, education, perceptions of soil fertility, irrigation, the number of parcels and income outside farming. So this research has hypothesized that the factors influencing the level of technical inefficiency is the capability of managerial (way of information acquisition price of rice (unhulled rice) and the system of subsistence farmers), characteristics of farmers (age, education level, length of business, land status) and the behaviour of farmers in the face of production risk. Whereas, the allocation of the input will directly affect the level of technical efficiency.

By looking at the phenomenon of rice productivity rate in Malang Regency which highly volatile, it is possible the preferences of farmers in the face of production risk are quite a role in the level of technical efficiency achieved. Based on the above description, the purposes of this study are a) to measure the preferences of farmers against the risk, b) to analyze the level of technical efficiency taking into account the preferences of the farmers against the risks and c) to analyze the effect of preference of farmers to sources of technical inefficiency.

\section{MATERIALS AND METHODS}

Data collection is conducted in the rainy season of 2013 and the first dry season of 2014, using in-depth interviews to rice farmers of 305 people. The location selected purposively with consideration that regions with high productivity of rice, but productivity rate for 13 years is fluctuate sharply. The method of data analysis is the expected utility of income and Stochastic Frontier Translog production function, as follows:

The formulas of expected utility of income:

$$
\begin{aligned}
& \mathrm{EMV}=p_{1} \cdot \mathrm{I}_{\mathrm{a} 1}+p_{2} \cdot \mathrm{I}_{\mathrm{a} 2} \\
& \mathrm{E}(\mathrm{U})=p_{1} \mathrm{U}\left(\mathrm{I}_{1}\right)+p_{2} \cdot \mathrm{U}\left(\mathrm{I}_{2}\right) \\
& \text { Utility of Income } \\
& \text { Utility of Income } \left.\left(\mathrm{U}\left(\mathrm{I}_{1}\right)\right)=\mathrm{E}\left(\mathrm{Py}_{1}\right)^{*} \mathrm{E}\left(\mathrm{I}_{2}\right)\right)=\mathrm{E}\left(\mathrm{Py}_{1}\right){ }^{\star} \mathrm{E}\left(\mathrm{Y}_{2}\right)
\end{aligned}
$$

where: EMV (Expected Money Value) is the expectation of the average actual income on the perception of two seasons. $E(U)$ (Expected Utility) is the sum of the utility derived from the income expectations of the risks that may occur in two seasons. $E M V-E(U)$ is an opportunity of money value earned, where it shows a preference of farmers to risks, $p_{1}=$ probability of income to the perception of a good season, $p_{2}=$ probability of income to the perception of bad season, $I_{1}=$ expected income during the rainy season, $I_{2}=$ expected income during the dry season, $\mathrm{I}_{\mathrm{a} 1}=$ actual income during the rainy season, $\mathrm{I}_{\mathrm{a} 2}=$ actual income during the dry season, $\mathrm{E}\left(\mathrm{Py}_{1}\right)=$ expected output prices based on the risks that accompany the rainy season, $E\left(Y_{1}\right)=$ expected harvest result based on the risks that accompany the rainy season, $\mathrm{E}\left(\mathrm{Py}_{2}=\right.$ expected output prices based on the risks that accompany the dry season, $E\left(Y_{2}\right)=$ expected harvest result based on the risks that 
accompany the dry season. Farmer preference indicator is said to be risk averter when $\mathrm{I}_{\mathrm{a}}<$ $E M V$, said risk taker when $I_{b}>E M V$, and said to be risk neutral when $I_{c}=E M V$.

Technical Efficiency Analysis of Rice Farming:

Frontier translog productivity function (Christensen, L. R.,1973) is used to measure the level of technical efficiency. The parameters of the stochastic frontier production function estimated using Maximum Likelihood Estimators. The completion of the model using Frontier 4.1 software program. The level of efficiency and inefficiency sources analysed from frontier translog productivity function simultaneously. Equation (5) and (6) are:

$$
\begin{gathered}
Y_{i t}=\exp \left(\beta_{0}+\sum_{h=1}^{N} \beta_{h i t} \ln x_{h i t}+\frac{1}{2}\left(\beta_{h_{i t} h_{i t}}\right)^{2}+\sum_{h=1}^{N} \sum_{m=1}^{N} \beta_{h_{i t} m_{i t}} \ln x_{h i t} \ln x_{m i t}+D t e k n\right)+v_{i}-u_{i} \\
\operatorname{Ln~} \mathrm{u}_{i t}=\delta_{1} \ln \mathrm{Z}_{1 \mathrm{t}}+\delta_{2} \ln \mathrm{Z}_{2 \mathrm{t}}+\delta_{3} \ln \mathrm{Z}_{3 \mathrm{t}}+\delta_{4} \ln \mathrm{Z}_{4 \mathrm{t}}+\delta_{5} \ln \mathrm{Z}_{5 \mathrm{t}}+\delta_{6} \ln \mathrm{Z}_{6 \mathrm{t}}+\delta_{7} \ln \mathrm{Z}_{7 \mathrm{t}}
\end{gathered}
$$

where: $\beta_{\text {hit }}$ : alleged parameters for input to the $\mathrm{h}$-th on the productivity frontier in individuals to the $\mathrm{i}$-th on growing season to the $\mathrm{t}$-th, $\beta_{\mathrm{hm}}$ : alleged parameters for interaction input to $\mathrm{h}$-th with an input to the $\mathrm{m}$-th toward frontier productivity, $\ln \mathrm{Y}_{\mathrm{it}}$ productivity of dry-milled rice on individual to the $\mathrm{i}$-th in the growing season to the $\mathrm{t}$-th $(\mathrm{kg}), x_{\text {hit }}$ : input to the $\mathrm{h}$-th on individual to the $\mathrm{i}$-th in the growing season to the $\mathrm{t}$-th, $\ln x_{\text {hit }} \ln x_{\text {mit }}$ : natural lag which shows the interaction between inputs used on each individual to the $i$-th and the growing season to the $\mathrm{t}$-th, $\mathrm{e}_{\mathrm{it}}=\mathrm{v}_{\mathrm{it}}-\mathrm{u}_{\mathrm{it}}, \mathrm{u}_{\mathrm{it}}=$ random variable of non-negatively associated with technical inefficiency, $\mathrm{N}\left(0, \sigma_{u}^{2}\right), v_{\text {it }}=$ statistical errors iid $\mathrm{N}\left(0, \sigma_{v}^{2}\right)$, Dtehn = dummy technology where the number 0 indicates not to apply the technology and number 1 show applying technology. Input variables are seed, urea, ZA, NPK Phonska, SP-36, organic fertilizers, male labour, female labour, a solid chemical drugs and a liquid chemical drugs.

Furthermore, the alleged effects of technical inefficiency caused by age of farmers $\left(Z_{1}\right)$, education level of farmers $\left(Z_{2}\right)$, farming duration $\left(Z_{3}\right)$, land ownership status $\left(Z_{4}\right)$, the system of subsistence $\left(Z_{5}\right)$, how to obtain information of output prices $\left(Z_{6}\right)$ and farmer preferences against the risks $\left(Z_{7}\right)$. With simultaneous estimation procedure, will get the estimators for $\alpha$, $\delta, y$ and $\sigma_{\mathrm{s}}{ }^{2}$ where $\sigma_{\mathrm{s}}{ }^{2}=\sigma_{u}^{2}+\sigma_{v}^{2} ; \gamma=\sigma_{u}^{2} / \sigma_{v}^{2} ;$ Three hypotheses were proposed: $\mathrm{H}_{\mathrm{o}}: \alpha_{\mathrm{hm}}=\alpha_{\mathrm{h}}$ $=\beta \mathrm{hm}=\beta \mathrm{h}=0 ; \mathrm{H}_{0}: \delta_{1}=\delta_{2}=\delta_{3}=\delta_{4}=\delta_{5}=\delta_{6}=0 ; \mathrm{H}_{0}: \gamma=0 ;$ (no impact on technical inefficiency and all deviations derived from statistical errors). Statistic test of likelihood ratio is used hypothesis test above: $\lambda=-2\left(\ln \left(L\left(\mathrm{H}_{0}\right) / L\left(\mathrm{H}_{1}\right)\right)\right.$ where $L\left(\mathrm{H}_{0}\right)$ is the likelihood function with a null hypothesis and $L\left(H_{1}\right)$ is a likelihood function with the hypothesis $1 . H_{0}$ will be rejected if $\lambda$ exceeds the value of $(1-\alpha) 100 \%$ for the chi-square distribution with two degrees of freedom, where $\alpha$ is the size of the test concerned. Distribution of $x_{2}^{2}$ is included because the distribution of the $u_{i}$ is two specific parameters, $\mu$ and $\sigma^{2}$.

The technical efficiency of individual to the $i$-th, denoted as $T E_{i}$, with the value of certain explanatory variables, $X_{i}$ is defined by the ratio between the average production of the $i$-th, with real value due to the impact of the $i$-th; $u_{i}$ with production inefficiencies to the average production if there is no production inefficiency (Battese and Coelli, 1992), namely:

$$
\mathrm{TE}_{\mathrm{i}}=\frac{\mathrm{E}\left(Y i \mid x_{i}, U_{i}\right)}{\mathrm{E}\left(Y i \mid x_{i}, U_{i}=0\right)}(7)
$$

\section{RESULTS AND DISCUSSION}

The number of rice farmer preference in the face of the highest risk is risk averter farmer of $77.70 \%$, the number of farmer who prefers to face the risk is risk taker of $20.33 \%$ and risk neutral farmer is only $1.97 \%$ (Table 1 ).

Preferences of risk averter denoted number 1, risk neutral notation is number 2 and risk taker notation is number 3 . While the application of technology is used as a dummy to observe whether there are differences in the productivity of rice produced between the rainy season and the dry season due to the application of technology. The application of 
technology is denoted number 1 when farmers apply the technology recommended by the government according to the specification of location and time. The application of technology by the farmers, such as Jajar Legowo (Java's term) with various methods of plant spacing, System of Rice Intensification (SRI), Integrated Pest Management - Farmer Field School, Program of balanced fertilization and the use of improved seed. And conversely, farmers who do not apply the recommended technology by government, denoted by the number 0 . In the rainy season farmers in the research area by $47.68 \%$ and in the dry season by $22.95 \%$, which does not apply the technology.

Table 1 - Distribution of Rice Farmers Risk Behaviour

\begin{tabular}{lll}
\hline Risk Behaviour & Total (person) & Percentage (\%) \\
\hline \hline Risk Averter & 237 & 77.70 \\
Risk Taker & 62 & 20.33 \\
Risk Neutral & 6 & 1.97 \\
\hline
\end{tabular}

According to Karagiannis (2003), the formulation of the impact of inefficiency has three advantages, as follows 1) the equation allows the prediction and explanation of the impact of inefficiencies in the use of single-step estimation procedure, as long as the impact of inefficiency on $u_{i t}$ is a stochastic, 2) equation can also be used technical efficiency with timevarying of technical change using estimates of single-step, during the inefficiency impact is stochastic and truncated half-normal distribution, 3) despite using truncated half-normal distribution, but it can be interpreted that technical inefficiency effects are farm-specific.

The equation solved by a single equation approach to the estimation procedure MLE (Maximum Likelihood Estimation) using Frontier version 4.1.c. developed by Coelli (1996). Maximum Likelihood (ML) method consists of estimation of the parameters that are unknown in their behaviour that the probability of observing a predetermined productivity variable is done the maximum extent possible. Variance parameter of the likelihood function estimated at $\sigma^{2}=\sigma_{v}^{2}+\sigma_{u}^{2}$ and $Y=\sigma_{u}^{2} / \sigma^{2}$, while the result is $\sigma_{v}^{2}=0.11$ and $\sigma_{u}^{2}=0.262$ so that $\sigma^{2}$ by 0.372. According to Gujarati (2013) that the larger the sample used for the estimation of ML, then $\sigma^{2}$ will converge toward the real $\sigma^{2}$, and the difference estimator will be smaller between OLS and MLE estimates. By putting the value of the log likelihood function estimator, the obtained value of the log likelihood function when the OLS at -156.8 and maximum value at 118.6 that no other values of the parameters which will provide a higher probability in the analysis.

While the $Y$ value by 0.859 indicates that the estimated $Y$ value approaches a value of 1 , stating that the highest probability that the inefficiency is a significant impact on stochastic frontier models, and the average production function is not sufficiently represent the technology of farming. It means that the gamma of 0.859 indicates that for $85.9 \%$ of the total variation of rice production with a confidence level of $99 \%$ to farmers, because it is caused by technical inefficiency among farmers. In other words, rice production can be optimized if the technical inefficiency among farmers minimized.

Some hypotheses can be tested using statistical of the generalized likelihood-ratio, which LR test amounted to 76.48 obtained from the log likelihood $\mathrm{H}_{0}$ and $\mathrm{H}_{1}$, with restrictions 8 is greater than the critical point at the $99.5 \%$ confidence level of 21.96 , which means that the alternative hypothesis is accepted. Among others, 1) that the independent variables have an influence on the dependent variable in the equation of technical efficiency, 2) that the independent variables have an influence on the dependent variable in the equation of technical inefficiency and 3) $Y$ is a stochastic variable. From the frontier analysis, partially interpreted that the factors affecting positively and significantly on the level of technical efficiency are fertilizers of urea, NPK Phonska, and SP-36, education level of farmers and farmers' risk behaviour, otherwise factors that affect negatively the technical efficiency level and significant are the use of male labour and subsistence system.

The advantages of the translog production function are able to analyse the effect of sustainability increasing productivity potential if (1) the use of each input is add more and (2) the interaction between the use of inputs. From the estimation of factors that influence 
positively and significantly (by $90-99 \%$ confidence level) was added labour of male. The potential productivity will be increased by $0.152 \%$ if there are additional workforce of $1 \%$. These results are not consistent with the previous analyses that the added amount of labour it will reduce $0.739 \%$ productivity, interpretation of productivity improvement sustainability can be achieved if there are additional male labour by 0.152 .

In addition, the translog production function can estimate with detail, relationship or interaction between different inputs used. A negative sign would indicate a relationship between the inputs interchangeable, and conversely a positive sign indicates a complementary relationship or both inputs that complement each other. Significant substitution relationships shown in the interaction between the input use of seed-fertilizers of urea, SP-3 - male labour, and organic fertilizer - female labour. Meanwhile, a complementary relationship is shown in the interaction between male labour - female labour, fertilizer of urea - male labour, and ZA fertilizer - liquid chemical drugs.

Interaction between inputs indicate the law of Marginal Rate of Technical Substitution (MRTS), where the input which one added it will lead to other inputs also increased, if the sign is positive, and vice versa input which one added it will lead to reduce the use of other inputs will be indicated with a negative sign.

Table 2 - Frontier Translog Productivity Function

\begin{tabular}{|c|c|c|c|c|c|c|c|c|}
\hline No & Variables & $\begin{array}{c}\text { Estimate } \\
\text { Parameters }\end{array}$ & No & Variables & $\begin{array}{c}\text { Estimate } \\
\text { Parameters }\end{array}$ & No & Variables & $\begin{array}{c}\text { Estimate } \\
\text { Parameters }\end{array}$ \\
\hline & Intercept & $8.347^{\star \star \star \star}$ & 28 & In $\mathrm{B} \ln \mathrm{OK}$ & 0.031 & 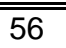 & $\overline{l n} \mathrm{O} \ln \mathrm{TL}$ & 0.0224 \\
\hline 1 & $\ln B$ & 0.017 & 29 & $\ln B \ln O L$ & -0.022 & 57 & $\ln O \ln \mathrm{TP}$ & $-0.0469^{\star \star \star \star}$ \\
\hline 2 & $\ln U$ & $0.359^{\star \star \star \star}$ & 30 & $\ln U \ln Z A$ & -0.0067 & 58 & In O In OK & -0.0052 \\
\hline 3 & In ZA & -0.004 & 31 & $\ln U \ln P S$ & -0.007 & 59 & $\ln \mathrm{O} \ln \mathrm{OL}$ & 0.006 \\
\hline 4 & In PS & $0.1^{\star \star \star}$ & 32 & $\ln U \ln S P$ & 0.0003 & 60 & In TL In TP & $0.07^{* * * *}$ \\
\hline 5 & In SP & $0.147^{\star \star \star}$ & 33 & $\ln U \ln O$ & 0.016 & 61 & In TL In OK & 0.0098 \\
\hline 6 & $\ln O$ & -0.048 & 34 & In U In TL & -0.0178 & 62 & In TL In OL & 0.0093 \\
\hline 7 & $\ln \mathrm{TL}$ & $-0.739^{\star \star *}$ & 35 & In U In TP & $0.0134^{* *}$ & 63 & In TP In OK & 0.017 \\
\hline 8 & In TP & -0.18 & 36 & In U In OK & -0.003 & 64 & In TP In OL & 0.019 \\
\hline 9 & In OK & -0.141 & 37 & $\ln U \ln O L$ & 0.0048 & 65 & In OK In OL & 0.0028 \\
\hline 10 & In OL & -0.116 & 38 & In ZA In PS & 0.00175 & 66 & D TEHN & 0.0297 \\
\hline 11 & $\ln B \ln B$ & $0.0557^{*}$ & 39 & In ZA In sp & -0.0048 & \multicolumn{3}{|c|}{ Technical inefficiency: } \\
\hline 12 & $\ln U \ln U$ & -0.0028 & 40 & $\ln \mathrm{ZA} \ln \mathrm{O}$ & 0.00335 & 1 & Age of farmer & 0.0038 \\
\hline 13 & $\ln \mathrm{ZA} \ln \mathrm{ZA}$ & -0.00656 & 41 & $\ln \mathrm{ZA} \ln \mathrm{TL}$ & 0.0195 & 2 & Education level & $-0.21^{* * * *}$ \\
\hline 14 & In PS In PS & -0.0135 & 42 & $\ln \mathrm{ZA} \ln \mathrm{TP}$ & -0.01 & 3 & Farming duration & -0.0041 \\
\hline 15 & $\ln \mathrm{SP} \ln \mathrm{SP}$ & 0.0055 & 43 & In ZA In OK & 0.0074 & 4 & Land ownership & 0.02 \\
\hline 16 & $\ln \mathrm{O} \ln \mathrm{O}$ & 0.0081 & 44 & $\ln \mathrm{ZA} \ln \mathrm{OL}$ & $0.013^{* *}$ & 5 & Subsistence System & $0.258^{* * * *}$ \\
\hline 17 & In TL In TL & $0.152^{\star * \star *}$ & 45 & In PS In SP & -0.0027 & 6 & Price Information & 0.075 \\
\hline 18 & In TP In TP & 0.0078 & 46 & In $P S \ln O$ & 0.00016 & 7 & PR & $-0.622^{\star * \star *}$ \\
\hline 19 & In OK In OK & -0.024 & 47 & In PS In TL & -0.019 & \multicolumn{3}{|c|}{ Hypothesis Test: } \\
\hline 20 & $\ln \mathrm{OL} \ln \mathrm{OL}$ & 0.009 & 48 & $\ln P S \ln T P$ & $0.0238^{*}$ & 1 & sigma squared & 0.262 \\
\hline 21 & $\ln B \ln U$ & $-0.05^{\star \star \star \star}$ & 49 & In PS In OK & 0.0027 & 2 & gamma & 0.859 \\
\hline 22 & $\ln B \ln Z A$ & 0.0067 & 50 & In PS In OL & -0.0084 & 3 & log likelihood fc & -118.6 \\
\hline 23 & In B In PS & -0.00226 & 51 & $\ln \mathrm{SP} \ln \mathrm{O}$ & -0.00076 & 4 & $L R$ test & 76.48 \\
\hline 24 & $\ln B \ln S P$ & -0.008 & 52 & In SP In TL & $-0.02^{*}$ & 5 & restricts & 8 \\
\hline 25 & $\ln \mathrm{B} \ln \mathrm{O}$ & 0.013 & 53 & In SP In TP & 0.0019 & & & \\
\hline 26 & In B In TL & 0.02 & 54 & In SP In OK & 0.00013 & & & \\
\hline 27 & $\ln B \ln T P$ & -0.0043 & 55 & In SP In OL & -0.0015 & & & \\
\hline
\end{tabular}

${ }^{* * *} \operatorname{sign} 99.5 \%,{ }^{* * *} \operatorname{sign} 97.5 \%,{ }^{* *} \operatorname{sign} 95 \%$ and ${ }^{*} \operatorname{sign} 90 \%$

The application of technology in the research area in two cropping seasons show that no difference in the effect of the technology application to the rice productivity. Partially means that an increase of $1 \%$ urea fertilizer will lead to an increase in the productivity potential of $0.359 \%$, less than $1 \%$. Currently, the average use of urea by $291 \mathrm{~kg} /$ hectare in the rainy season and by $298.8 \mathrm{~kg} /$ hectare, is almost accordance with the recommendations of government by $200-300 \mathrm{~kg} /$ hectare. Nevertheless, when farmers add $1 \%$ of this amount by $2.91 \mathrm{~kg}$ in the rainy season and $2.98 \mathrm{~kg}$ in the dry season, the production of rice obtained 
an increase by $0.359 \%$ from the average production produced which rose by $23.36 \mathrm{~kg}$ in the rainy season and $24.52 \mathrm{~kg}$ in the dry season.

In the research area, the average use of NPK Phonska fertilizer of $180.8 \mathrm{~kg} /$ hectare in the rainy season and $181.6 \mathrm{~kg} /$ hectare during the dry season; while the government's recommendation for the use of fertilizer is $150-200 \mathrm{~kg} / \mathrm{ha}$. From the estimation, NPK Phonska fertilizer increases by $1 \%$ would lead to a potential increase in productivity only by $0.1 \%$. When farmers add the fertilizer approximately $1.8 \mathrm{~kg}$, it will obtain an increase in productivity of $6.5 \mathrm{~kg} /$ hectare in the rainy season and $6.83 \mathrm{~kg} /$ hectare in the dry season.

The average use of SP-36 fertilizer is $43 \mathrm{~kg} /$ hectare during the rainy season and $130.7 \mathrm{~kg} /$ hectare during the dry season; while the government's recommendation for the use of fertilizer is $100-150 \mathrm{~kg} / \mathrm{ha}$. From the estimation results, an increase in SP-36 fertilizer is only $1 \%$ would lead to a potential increase in productivity by $0.147 \%$. When farmers add SP-36 fertilizer approximately $4.3 \mathrm{~kg}$ in the rainy season and by $13.07 \mathrm{~kg} /$ hectare during the dry season, it will obtain an increase in productivity of the rainy season by $9.5 \mathrm{~kg} /$ hectare and $10 \mathrm{~kg} /$ hectare in the dry season.

Education level and risk behaviour of farmers have a negative sign of the impact of technical inefficiency, indicating that the higher the education level of farmers will reduce the level of technical inefficiency reached by farmers. The average level education of farmer in the research area is elementary high school, if the level of education increased, such as following the open education of junior and senior high school to elderly farmers and formal education such as extension and education of technology cultivation, it will affect a decrease in the level of technical inefficiency farming. The level of education of elementary upgraded to junior level and can further help to decrease the impact of technical inefficiency at $0.22 \%$.

Farmer preference in the face of risk proved significantly and negatively affect with the confidence level of $99.5 \%$ by 0.62 , which means that the reduction of technical inefficiency by $0.62 \%$ due to the increase in farmers' courage in the face of farming risk of $1 \%$. Farmer preferences can be improved by induction technology with continuous assistance, so that there is an increase in the courage to take additional income opportunities from risk averter to risk neutral.

Conversely, factors affecting the decrease in frontier productivity impact on the decrease of rice farming efficiency is the use of male labour and subsistence system. Every increase in the use of men labour by $1 \%$ or 7 people per hectare, it will lower the productivity potential by $0.739 \%$ or $48 \mathrm{~kg} /$ hectare during the rainy season and $50.47 \mathrm{~kg} / \mathrm{ha}$ during the dry season. According to the one extension in Singosari District, Malang Regency, that the use of male labour for land preparation activities are quite a lot and seized about 5 days, but on average only 60 people per hectare per planting season. Thus, it need to reduce the use of male labour in the farming activities.

The analysis result of the technical efficiency level of rice in Malang Regency in average panel data is $76.5 \%$, thus the efficiency is achieved at a high category. Meanwhile, when averaged of each planting season with cross section data on average at $77 \%$ of the rainy season and the dry season amounted to $75.9 \%$. (Table 3 ).

Table 3 - Distribution of Farmer Efficiency Level Based on Season

\begin{tabular}{ccccc}
\hline \multirow{2}{*}{ Category } & \multicolumn{3}{c}{ Season } & \multicolumn{2}{c}{ Dry } \\
\cline { 2 - 5 } & Total (person) & $\%$ & Total (person) & $\%$ \\
\cline { 2 - 5 } & 37 & 12.13 & 29 & 26.89 \\
$0.31-0.51$ & 71 & 23.28 & 82 & 63.61 \\
$0.52-0.72$ & 197 & 64.59 & 194 & 100 \\
\hline-0.95 & 305 & 100 & 305 & \\
\hline
\end{tabular}

A total of $64.59 \%$ of the farmers are in the category of a high level of technical efficiency in the rainy season, the condition is also experienced by farmers in the next season namely the dry season with the number of farmers by $63.61 \%$. Although farmers have achieved high levels of efficiency, keep in mind also the opportunity to improve the 
technical efficiency is up to $100 \%$. Sources of inefficiency can be analysed simultaneously with the frontier translog productivity function, which had been discussed earlier.

Descriptive statistics, shown in Table 4 that the higher the level of technical efficiency, the higher the percentage of farmers who implement technology well in the rainy season and the dry season.

Table 4 - Distribution of Farmer Efficiency Level Based on the Technology Application

\begin{tabular}{ccc}
\hline \multirow{2}{*}{ Category } & \multicolumn{2}{c}{ Technology Application (\%) } \\
\cline { 2 - 3 } & Rainy Season & Dry Season \\
\hline \hline $0.31-0.51$ & 1.64 & 5.25 \\
$0.52-0.72$ & 15.41 & 18.03 \\
$0.73-0.95$ & 35.08 & 54.10 \\
\hline \hline
\end{tabular}

When the frequency distribution efficiency level is based on the farmers' risk behaviour, it is presented in Table 5, which shows that the descriptive statistical behaviour of farmers who prefer to take the risk tend to have a high level of efficiency both in the rainy season and the dry season. In accordance with the theory, that the conduct would rather avoid the risk of using resources inefficiently (Ellis, 1988).

Table 5 - Distribution of Farmer Efficiency Level Based on Risk Behaviour (\%)

\begin{tabular}{ccccccc}
\hline \multirow{2}{*}{ Category } & \multicolumn{3}{c}{ Rainy Season } & \multicolumn{3}{c}{ Dry Season } \\
\cline { 2 - 7 } & Risk averter & Risk neutral & Risk taker & Risk averter & Risk neutral & Risk taker \\
\hline \hline $0.31-0.51$ & 10.13 & - & - & 11.39 & - & - \\
$0.52-0.72$ & 26.58 & - & 20.97 & 30.38 & - & 1.61 \\
$0.73-0.95$ & 63.29 & 100 & 79.03 & 58.23 & 100 & 98.39 \\
\hline \hline
\end{tabular}

In the rainy season, the risk averter behaviour of the average reached a level of technical efficiency by 0.742 , if the interval category, entered on high technical efficiency by $63.29 \%$. A number of $10.13 \%$ risk averter farmers achieve technical efficiency among 0.31 to 0.51 is a low category, and approximately $63.29 \%$ of risk averter farmers has achieved a high technical efficiency (Table 5 and Figure 1). However, the average level of efficiency, the difference is quite far with risk neutral farmer (0.877) and a risk taker (0.802) during the rainy season. For farmers risk neutral, $100 \%$ of the farmers have achieved a high level of technical efficiency. As for the farmers risk taker, there is $20.97 \%$, which still achieve moderate levels of efficiency, and the remaining $79.03 \%$ was reached efficiently. (Table 5 and Figure 2).

Rainy Season

$\square .31-0.51 \square 0.52-0.72 \square 0.73-0.95$

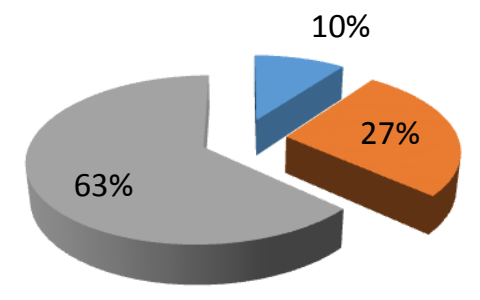

Dry Season

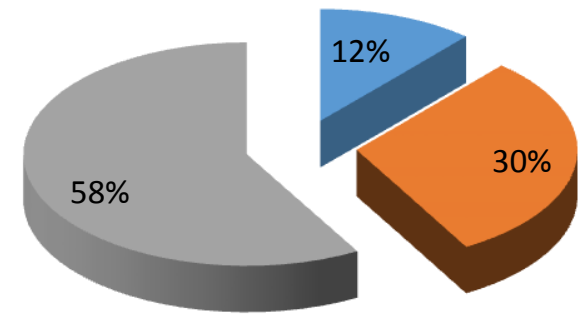

Figure 1 - Distribution of Risk Averter Farmer Based on Technical Efficiency Level (\%) 
Rainy Season

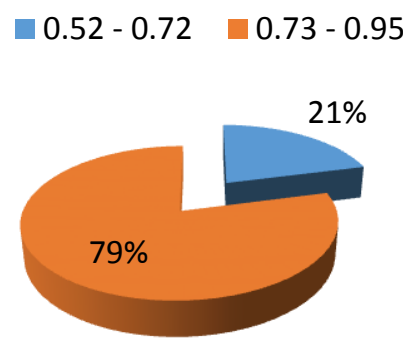

Dry Season

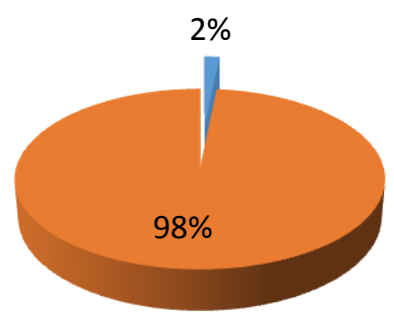

Figure 2 - Distribution of Risk Taker Farmer Based on Technical Efficiency Level (\%)

In the dry season, risk averter behaviour is enough to change, a high level of technical efficiency tends to shift into a moderate and low technical efficiency, $58.23 \%, 30.38 \%$ and $11.39 \%$ respectively. While, the risk neutral farmer remains at $100 \%$ the number of farmers who achieve high technical efficiency. Difference with behavioural risk averter, risk taker farmers tend to shift can achieve high efficiency levels of $98.39 \%$. Although a high level of technical efficiency can be achieved by these three groups of farmers, but the average behaviour is different, that average level of technical efficiency of risk averter farmer of 0.723 , the average risk-neutral of 0.848 , and the average risk taker of 0.892 .

\section{CONCLUSIONS}

The most rice farmer preferences is risk averter (farmers who prefer to avoid the risk) of $77.7 \%$. The level of technical efficiency significantly and positively influenced by the allocation of inputs (fertilizers of urea, NPK Phonska, and SP-36) and managerial capabilities of farmers (subsistence system adopted by farmers) and preferences of farmers in the face of risk. The average technical efficiency of risk averter farmer by 0.723 , risk neutral by 0.848 and risk taker by 0.892 . The results showed that the role of risk behaviour of farmers substantially to the achievement of efficiency and increase productivity, it is necessary to increase informal education (Integrated Pest Management - Farmer Field School), extension, mentoring technology, and insurance so that information for induction technology will be appropriate for farmers, thus expect an increase of courage farmers in taking a chance or opportunity to get income by improving the allocation and combination of farm inputs.

\section{REFERENCES}

1. Aigner D, C.A. Knox Lovell and Peter Schmidt, 1977. Formulation and Estimation of Stochastic Frontier Production Function Models. North-Holland Publishing Company. Journal of Econometrics 6: 21-37.

2. Aigner, D.J. and Chu, S.F. (1968). On Estimating the Industry Production Function. American Economic Review, 58(4): 826-39

3. Athipanyakul T, et al, 2014. Key Factors for Improving Technical Efficiency of Upland Rice Production. American Journal of Applied Sciences 11 (2): 266-272.

4. Battese, G. E., \& Coelli, T. J. (1992). Frontier production functions, technical efficiency and panel data: With application to paddy farmers in India. Journal of Productivity Analysis, 3(1/2), 153-169.

5. Battese,G.E., and T.J.Coelli, 1995. A Model for Technical Inefficiency Effects in a Stochastic Frontier Production Function for Panel Data. Empirical Economics, 20:325332.

6. Bravo-Uretra, B.E. and A.E. Pinheiro. 1997. Technical, Allocative and Economic Efficiency in Peasant Farming: Evidence from the Dominican Republic. The Developing Economies, 35(3): 48-67. 
7. Bravo-Ureta, B. E. and Pinheiro, A.E., 1993. Efficiency analysis of developing country agriculture: a review of the frontier function literature. Agricultural and Resource Economics Review. 22 (1): 88-101.

8. Bokhuseva, R. and H. Hockmann. 2004. Output Volatility in Russian Agriculture: The Significance of Risk and Inefficiency. Working Paper. Institute of Agricultural Development in Central and Eastern Europe (IOMA), Halle, 2: 06110.

9. Charyulu A.K and Biswas S, 2010. Economics and Efficiency of Organic Farming vis-àvis Conventional Farming in India. Indian Institute of Management. Ahmedabad. India. W.P. no. 2010-04-03: 1-26.

10. Christensen, L. R., Jorgensen D.W., and Lau L.J. 1973. Transcendental Logarithmic Production Frontier. Economics and Statistics Journal, 55(1): 28-45.

11. Coelli, T. 1995. Recent Developments in Frontier Modelling and Efficiency Measurement. Australian Journal of Agricultural Economics, 39 (3): 219-245.

12. 1996. A guide to Frontier Version 4.1: A Computer Program for Stochastic Frontier Production and Cost Function Estimation. Centre for Efficiency and Productivity Analysis (CEPA). Working Paper 7/96. University of New England, Armidale, pp 1-33.

13. 2005. An Introduction to Efficiency and Productivity Analysis. Second Edition. Springer. USA, pp $241-261$.

14. Constantin,P. D,, Martin, A. L., and Rivera EDBB,2009. Cobb-Douglas, Translog Stochastic Production and Data Envelopment Analysis in Total Factor Productivity in Brazilian Agribusiness. The Flagship Research Journal of International Conference of the Production and Operations Management Society. 2 (2): 20-34.

15. Donkoh SA, et al. 2013.Technical Efficiency of Rice Production at the Tono Irigation Scheme in Northern Ghana. American Journal of Experimental Agriculture, 3(1): 25-42.

16. Ellis,Frank, 1988. Peasant Economics, Farm Household and Agrarian Development, Cambridge University Press, pp 80 - 101.

17. Farrell, M. J. 1957. The Measurement of Productive Efficiency. Journal of The Royal

18. Statistical Society, Series A, 120(3): 253-290.

19. Fauziyah, E., Hartoyo, S., Kusnadi, N., Kuntjoro, S. U., 2010. Analisis Produktivitas

20. Usahatani Tembakau di Kabupaten Pamekasan. Indonesia. Jurnal Organisasi dan Manajemen, 6: 119-131.

21. Galawat F dan Yabe M, 2011. An Analysis of Farm Level Technical Efficiency in the Rice Production in Brunei Darussalam: A Stochastic Frontier Approach. International Journal of Arts and Sciences. 4 (15): 21-31.

22. Guan H.Wan and George E. Battese, 1992. A Stochastic Frontier Production Function Incorporating Flexible Risk Properties. Paper presented at the Australian Meeting of the Econometric Society, Monash University, Melbourne, ISSN 0 157-0188, ISBN 186389 018: 1-18.

23. Ghosh $\mathrm{C}$ and Raychaudhuri, 2010. Measurement of Cost Efficiency in The Case of Rice Production in West Bengal and Andhra Pradesh, VII (1\&2): 30-47.

24. Hamal,B.K., 1983. Risk Perception and Credit Use: The Case of Small Paddy Farmers in Nepal. HMG-US AID-A/D/C Project. Strengthening Institutional Capacity in the Food and Agricultural Sector in Nepal. Research Paper Series, 21.

25. Islam, K.M.Z., J Sumelius, S Bäckman. 2012. Do differences in technical efficiency explain the adoption rate of HYV rice? Evidence from Bangladesh. Agricultural Economics Reviews 13 (1): 93-110.

26. Just, E.R, dan R.D. Pope. 1979. Production Function Estimation and Related Risk Consideration. American Journal Agricultural Economic, 6(2): 276-284.

27. JR.Anderson and WE. Griffiths.1982. Product Risk and Efficient Allocation of Resources.

28. Australian Journal of Agricultural Economics, 26(3): 226-332.

29. Karagiannis, G., V. Tzouvelekas, and A. Xepapadeas. 2003. Measuring irrigation water efficiency with a stochastic production frontier. Environmental and Resource Economics 26(1):57-72.

30. Kumbhakar, C S. 2002. Specification and Estimation of Production Risk, Risk Preferences and Technical Efficiency. American Journal Agricultural Economic, 84(1): 8-22. 
31. Kumbhakar, S.C., Ghosh, K. S. \& McGuckin, J. T. (1991). A Generalized Production Frontier Approach for Estimating Determinants of Inefficiency in US Dairy Farms. Journal of Business and Economic Statistics, 9(3): 279-286.

32. Kumbhakar,C.S and Tsionas E.G.,2008. Estimation of Cost vs Profit System with and without Technical Inefficiency. Academia Economic Papers. 36 (2): 145-166.

33. Kurniawan A.Y, 2012. Factors that influence the Technical Efficiency on Rice Tidal Land in Anjir Muara Anjir District Barito Kuala Regency South Kalimantan Province. Journal of Rural Agribusiness, 2 (1)

34. Lawal AM, et al, 2013. Assesment of The Economics and Resource-Use Efficiency of Rice Production in Ogun State Nigeria, Agris on-line Papers in Economics and Informations, 5(3): 9.

35. Mailena L, et al. 2014. Efficiency of Rice Farms and its Determinants: Application of Stochastic Frontier Analysis. Trends in Applied Sciences Research. Academic Journals Inc, ISSN 1819-3579 / DOI: 10.3923/Tasr.2014: 1-12

36. Murniati K, et al, 2014. The Technical Efficiency of Organic Rice Farming in Wetland Rain-fed in Tanggamus Regency Lampung Province. Journal of Applied Agricultural Research, 14: 31-38.

37. Mohapatra, R., 2013. Farm Level Technical Efficiency in Paddy Production: A Translog Frontier Production Function Approach. International Journal of Advanced Research, 1(3): 300-307.

38. M.K.Hossain, 2013. Impact of Environment Factors on Efficiency of Rice Production in Bangladesh. Journal of Applied Sciences, 13 (4): 564-571.

39. Piya S, A. Kiminami and H.Yagi, 2012. Comparing the Technical Efficiency of Rice Farms in Urban and Rural Areas: A Case Study from Nepal. Trends in Agricultural Economics, 5 (2): 48-60.

40. Poudel KL, et al, 2011. Comparing Technical Efficiency of Organic and Conventional Coffee Farms in Nepal using Data Envelopment Analysis Approach. Annual Conference of the Agricultural Economics Society, 85 rd: 1-32.

41. Pope, Rulon D. And Randall A. Kramer. 1979. "Production Uncertainty and Factor Demans for the Competitive Firm." So. Econ. J., 46:489-501.

42. Prayoga 2010. Productivity Analysis, and Technical Efficiency of Organic Rice Farming Income, as well as Application Level of Organic Farming Rice, Manuscript Dissertation of Doctoral Program of Agricultural Sciences University of brawijaya Indonesia. Unpublished.

43. Saptana, 2012. Concept of Food Farming Efficiency and Its Implications for Increased Productivity. Agro Economic Research Forum, 30(2): 109-128.

44. Suharyanto et al. 2013. Analysis of Technical Efficiency of Integrated Crop Management of Rice in Bali. SEPA Journal. Indonesia, 9(2): 219-230.

45. Ureta, B, E. and Antonio E. Pinheiro. 1997. Technical, Economic, and Allocative Efficiency in Peasant Farming: Evidence from the Dominican Republic. The Developing Economies, XXXV-1 (March 1997): 48-67.

46. Meeusen, W. and van den Broeck, J. (1977). Efficiency Estimation from Cobb-Douglas production functions with composed error. International Economic Review, 18: 435-444.

47. Villano,R and Euan Fleming,2006. Analysis of Technical Efficiency in a Rainfed Lowland Rice Environment in Central Luzon Philippines Asian Economics, 49(3): 294-305.

48. Watkins KB, et al, 2014. Measurement of Technical, Allocative, Economic and Scale Efficiency of Rice Production in Arkansas Using Data Envelopment Analysis. Journal of Agricultural and Applied Economics. Southern Agricultural Economics Association, 46(1): 89-106.

49. Wik, M., S. Holden and E.Taylor, 1998.Risk, Market Imperfections and Peasant Adaptation: Evidence from Northern Zambia. Discussion Paper D-28, Department of Economics and Social Sciences. The Agricultural University of Norway. 